\title{
Do service activity impact on the risk of Indonesian banking industry?
}

\author{
Yona Friantina ${ }^{1, \mathrm{a}}$, Ruhadi ${ }^{1}$ and M. Edman Syarief ${ }^{1}$ \\ ${ }^{1}$ Department of Islamic Banking and Finance, Bandung State Polytechnic, Bandung, Indonesia
}

\begin{abstract}
The Indonesian banking industry has developed technology innovation will provide financial services to generate income. The purpose of this paper is to compare the service activity and to explore the effect of the service activity on risk in Islamic and conventional banks. By analyzing 12 Islamic banks and 38 conventional banks in Indonesia during the period from 2015 to 2017, we use Structural Equation Modelling (SEM) with path analysis and multiple group analysis. The result shows that the service activity of Islamic banks appears to be more variable than conventional banks. The risk level of Islamic banks is more stable than conventional banks. For Islamic banks, non-financing income has a significant negative effect on risk, commission income and trading income have a significant positive effect on risk, and other non-financing income has no effect on risk. However, no significant effect has been observed between non-interest income, commission income, trading income, other non-interest income and risk level in conventional banks. This finding indicates that the combination of funding activities, lending activities, and service activities allows Islamic banks to obtain the diversification income till reduce risks. For conventional banks, diversification in activities contributes to the higher volatility of bank revenue.
\end{abstract}

\section{Introduction}

The development of information technology can change the behavior of everyday society in conducting financial transactions with banks. In this era, the public would require effective and efficient financial transaction services. In the banking system, financial transaction services depend on customer demand. Bankers, as in other service industry, must accommodate all customers' needs so that compete in the industry [21]. Financial transaction services open new innovations that must be supported by professional human resources and information technology that has been prepared in order to improve the quality of banking services and facilities. The innovation of banking products and services shows that the bank is increasingly diversified its business activities.

The diversification of banking business activities in terms of financial services such as transfer, collection, letter of credit, safe deposit box, etc., then the banking will generate profits called fee-based income. In banking, the income earned from this fee-based income plays a very important role as an alternative source of income, thereby reducing the over-

\footnotetext{
${ }^{\text {a }}$ Corresponding author : yona.friantina@gmail.com
} 
reliance on funding activities and lending activities that are the main source of income [22]. The bank services consist of commission and provision income, revenue from foreign exchange transactions, and other operating income. Income derived from these bank services are relatively small but contain a certainty. This is because the risk of these bank services is smaller than the credit/ financing. Conventional banks are known as non-interest income but Islamic banks are expressed as non-financing income that is unrelated to the funding activities and lending activities [15].

In general, banks that diversify incomes through the providing of financial services to both conventional banks and Islamic banks are very useful to reduce risks in the banking industry. Several studies have discussed this problem, but no study has been conducted banking service activities on the risks in Indonesia context of Islamic banks and conventional banks, and also different risk measurement methods from previous studies using the parameters of the solvency ratio. Moreover, there is the difference in applying the analysis method that uses Structural Equation Modeling (SEM) with path analysis.

This study aims to compare risk and service activities in Islamic banks and conventional banks in Indonesia as well as to analyze the impact of banking service activities on risks, as an independent variable consists of non-interest income, commission income, trading income and other non-interest income and as a dependent variable measured by the debt to equity ratio between Islamic banks and conventional banks in Indonesia during the period 2015-2017. This study consist of several sections. First, it will begin with the introduction. Next, in the second part, the theoretical review will be explained. Third, the methodology used in this study. Fourth, the result. Last, the conclusion followed by the important implication and future research of this study.

\section{Literature Review}

According to Rivai and Ismal [20], uncertainty refers to the notion of an unexpected risk, whereas the term risk refers to the expected risks. In general, there are three sources that can cause uncertainty such as information, time, and ability/skill. In everyday life, we also often hear the term "high risk: high return". The term indicates a positive relationship between risk and profit levels. Means, the higher the risk the greater the return earned. Vice versa, the lower the risk the smaller the return.

Research on the risks and activities of banking services is not a new study. So far, a number of studies have been conducted by several researchers from international and Indonesia. The most recent research is conducted by Moudud-Ul-Huq, et al. [16] support that the diversification of income benefits the bank by improving performance and reducing risks. The study [19] shows that non-interest income as a whole is reducing bank risk in South Asia. Diversification is important because it increases bank income and also decreases the possibility of such pressure as the bank crisis [7]. Research conducted by Ekanayake and Wanamalie [4] found that risk-adjusted return on equity is positively influenced by higher non-interest income activities, indicating that a marginal increase in non-interest income increases trade-off shareholder risk. In contrast, the study [13] shows that diversification of non-traditional activities tends to increase bank risk regardless of bank size. Banks (especially dominant ones) migrated to non-traditional activities because these sources of income could be attributed to an increased risk of the bank as a whole [17].

In addition to research from abroad, researchers from Indonesia have also been researching the risks and activities of banking services. The research of [9] shows that the impact of product diversification on banks and insolvency risk is highly dependent on the size of bank assets. A study by Alfarisi [1] shows that Islamic banks earn relatively lower non-interest (traditional) income compared to conventional banks. A recent study 
conducted by Hardianto and Wulandari [8] found that Islamic banks have a higher feebased service activity compared to conventional banks.

\section{Method}

This study uses secondary data obtained from the publication of financial statements issued by the Financial Services Authority. The data used as the sample is taken by using purposive sampling method. Thus, the researcher determines the company based on several criteria of assessment as follows: 1) Commercial banks operating in Indonesia since the second quarter of 2015 until the fourth quarter of 2017 and routinely publish financial reports reported to the Financial Services Authority. 2) Conventional banks already listed on the Indonesia Stock Exchange (IDX) no later than March 31, 2015, and recorded until the fourth quarter of 2017. Based on these criteria, from the total of 116 commercial banks, 50 banks are made up of 38 conventional banks and 12 Islamic banks. Thus, the total observation of all research samples to 550 observations.

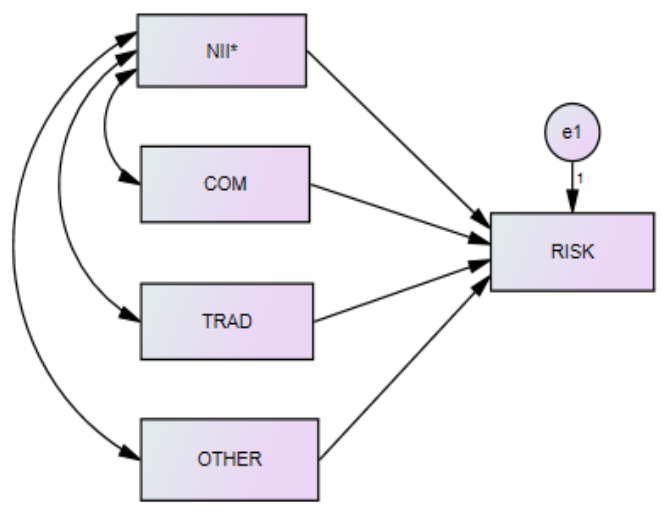

Fig. 1. Model Construction

This study provides a statistical description then the data is analyzed using Structural Equation Modeling (SEM) with data condition that has been a normal distribution. One of the advantages of SEM analysis is the ability to process models to predict the relationship between service activity and risk. SEM with path analysis is used because it can learn the direct effects (direct effect) and indirect effects (indirect effect) of the variable. There are several steps that must be passed in the path analysis. First, make a specification of the path analysis model. In making a path analysis model the relationship of one variable to another variable should be based on the existing theoretical basis. Second, make an estimate to get the path analysis coefficient. Third, conduct a path analysis significance test. Thus, the model to be used is as follows:

$$
\text { RISK }=\alpha_{1} \text { NII } *+\alpha_{2} \text { COM }+\alpha_{3} \text { TRAD }+\alpha_{4} \text { OTHER }+\mathrm{e}
$$

*NFI for Islamic bank

where NII is Non-Interest Income, COM is Commission Income, TRAD is Trading Income and OTHER is Other Non-Interest Income.

Furthermore, the researchers conducted a multiple group analysis that will divide the sample based on the characteristics of conventional banks and Islamic banks, with the following hypothesis: 
H0: There is no difference between two or more groups

H1: There are differences between two or more groups

We measure risk and service activity with four proxies: non-interest income, commission income, trading income and other non-interest income.

(a) Risk: Following Horne and Wachowicz [10], we use the parameters of the solvency ratio. Debt to equity ratio equals the ratio of total debt to shareholders' equity.

(b) Service activity: Following [9] and [14], we use non-interest income (NII) as the first proxy of service activity.

NII equals the ratio of non-interest income to total operating income, where non-interest income is the composition of commission income, trading income, and other non-interest income. Operating income is the summation of net interest income and non-interest income.

\section{Result}

The test result indicates that the goodness-of-fit index of the model is good (GFI: 0.961, AGFI: 0.805, NFI: 0.949, IFI: 0.955 and RMSEA: 0.128). We use multiple group analysis to compare Islamic and conventional that result is the probability level $(0,000)$ has below 0.05 ( $\mathrm{H} 0$ is rejected). This shows that there is a difference between an Islamic bank model and conventional bank model.

The risk rate of Islamic bank is more stable than a conventional bank. Islamic banks do not apply interest costs, so capital is not much needed for banking services activities. While the level of risk in conventional banks easily fluctuates due to the necessity to pay interest. However, service activity in Islamic banks is more variable than conventional banks, which is consistent with [3,8] that Islamic banks have higher service activity compared to conventional banks. Due to the limitations of Islamic banks in channeling funds directly, Islamic banks have various service products developed as service contracts to seek other income alternatives that reduce risk and increase profitability.

Table 1. The result of hypotheses testing

\begin{tabular}{|c|c|c|c|c|c|}
\hline Hypothesis & Path & $\alpha$ & C.R. & $\mathbf{P}$ & Note \\
\hline \multirow{2}{*}{$\mathrm{H} 1$} & RISK<--- NFI ${ }^{\mathrm{a}}$ & $-0,010$ & $-2,885$ & 0,004 & Supported \\
\hline & 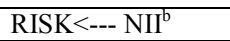 & 0,003 & 1,254 & 0,210 & Rejected \\
\hline \multirow{2}{*}{$\mathrm{H} 2$} & RISK $<---$ COM $^{\mathrm{a}}$ & 0,039 & 8,130 & $* * * *$ & Supported \\
\hline & RISK<--- COM ${ }^{b}$ & $-0,001$ & $-0,218$ & 0,827 & Rejected \\
\hline \multirow{2}{*}{$\mathrm{H} 3$} & RISK $<---$ TRAD $^{\mathrm{a}}$ & 0,141 & 2,427 & 0,015 & Supported \\
\hline & 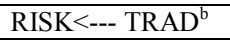 & $-0,006$ & $-0,209$ & 0,835 & Rejected \\
\hline \multirow{2}{*}{$\mathrm{H} 4$} & 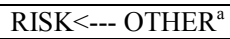 & 0,006 & 0,148 & 0,883 & Rejected \\
\hline & RISK $<---$ OTHER $^{b}$ & 0,004 & 0,175 & 0,861 & Rejected \\
\hline
\end{tabular}

$$
\begin{aligned}
& \text { RISK }=-0,010 \mathrm{NFI}+0,039 \mathrm{COM}+0,141 \mathrm{TRAD}+0,006 \text { OTHER }+\mathrm{e} \\
& \text { RISK }=0,003 \mathrm{NII}-0,001 \mathrm{COM}-0,006 \mathrm{TRAD}+0,004 \text { OTHER }+\mathrm{e}
\end{aligned}
$$

In Table 1, we can see from the results of Models (1a) that non-financing income (NFI) has a negative and significant relationship with risk (DER), which is consistent with $[5,7$, $9,16,18]$. The result shows that the increase of non-financing income will decrease the risk level so that banking service activity must be maximized. We look deeper by splitting nonfinancing income into commission income, trading income and other non-financing income in Model (1a). Similar to [9] we found that commission income (COM) shows a positive 
and highly significant relationship with risk. Trading income (TRAD) has shown a positive and significant relationship with risk, which is consistent with $[4,9,14]$. Other nonfinancing income shows a positive relationship with risk, which is not consistent with [4, 14, 19].

In Table 1, we can see from the results of Models (1b) that non-interest income (NII) has a positive relationship with risk (DER), which is consistent with [24]. The result shows that the increase in non-interest income has a positive impact direction while increasing diversification from non-interest income may have a negative impact on risk, not statistically significant. We look deeper by splitting non-interest income into commission income, trading income and other non-interest income in Model (1b). Similar to [4] and [14], we found that commission income (COM) has shown a negative relationship with risk. Trading income (TRAD) has shown a negative relationship with risk, which is not consistent with $[4,9,14]$. Other non-interest income shows a positive relationship with risk, which is not consistent with $[4,14,19]$.

Following past studies [22, 23], this study proposes Structural Equation Modeling (SEM) with path analysis to predict the relationship between exogenous and endogenous variables in the Indonesian banking industry context. From the category of Islamic banks, we estimate overall the impact of service activities can reduce risks represented by nonfinancing income. To test a deeper model of service activities, we use three proxies such as commission income, trading income, and other non-financing income. Commission income shows the strongest relationship in this SEM where increasing commission income will increase risk. Likewise, an increase in trading income shows a strong relationship to increased risk. Meanwhile, other non-financing income does not show the strength of the relationship only has a positive direction to risk. By measuring risk using this debt to equity ratio, we find interesting results for conventional bank categories. Compared to other risk measurement methods commonly used in analyzing the relationship of service activity and risk in conventional bank categories, this method can clearly help researchers understand the relationship of non-interest income, commission income, trading income and other noninterest income as proxies of service activities does not show the strength of the relationship to risk in this SEM.

\section{Conclusion}

This study examines the impact of service activity on risk in Islamic banks and conventional banks during the period 2015-2017. Service activity in Islamic banks is more variable than conventional banks. However, the level of risk in Islamic banks is more stable than conventional banks. In Islamic banks, service activity measured by non-financing income has a significant negative effect on risk, commission income has a significant positive effect on risk, trading income has a significant positive effect on risk and other non-financing income has no effect on risk. In conventional banks, service activities measured by non-interest income, commission income, trading income and other noninterest income have no effect on risk. The result of this study indicates that the combination of funding activities, lending activities, and service activities enable Islamic banks to gain diversified benefits thereby reducing risks. For conventional banks, diversification in activities shows that contribute to higher income volatility of banks.

The result of this study provides clear evidence that service activity led to Islamic banks can reduce bank risks well but in conventional banks, these service activities have a less obvious impact on bank risk. This study has important policy implications related to bank supervision from the perspective of bank risk in the Indonesian banking industry. Thus, the financial authorities should carefully monitor the behavior of Islamic banks associated with various bank and insolvency risks, such as financing risk, liquidity risk, operational risk, 
compliance risk, strategic risk, reputation risk, legal risk, the rate of return risk, equity investment risk, and market risk. Islamic banks operate as universal banks offering retail financing coupled with banking services. In accordance with the research [12], banks that expand into service activity will be more stable if the bank leads to a retail-oriented income. In this case, Islamic banks are expected to implement marketing strategies that lead to retail. Retail marketing strategy is done by small-scale allocation, its market characteristics as follows: 1) Has standard financial services products such as savings, demand deposits, time deposits, micro or consumptive financing, 2) Margin or interest rate refers to market price because retail business not too sensitive to the level of margin or interest rate, 3) The promotion is relatively large because the target is the number of customers, 4) Distribution service (marketing outlet) using $\mathrm{KC}, \mathrm{KCP}$, unit, and other media such as ATM, CDM, and mobile branch, 5) Retail business market more using personal approach, 6) Service is massive and service level agreement is relatively short, 7) Condition of building, decoration, layout, and others have an important role.

We have focused on discussions on how services activities affect risks in Islamic banks and conventional banks. However, when we examine the role of service activity in conventional banks does not affect the risk. For the next researcher can add the mediation variables to show the relationship between independent and dependent variables either direct or indirect effect so that the path analysis model used will be more complex.

\section{References}

1. Alfarisi, M.F., Impact of Financial Crisis on Non-Traditional Income: Islamic Banks Vis a Vis Conventional Banks. Journal of Islamic Finance, 2015. 4(1): p. 031-038.

2. Apergis, N., The long-term role of non-traditional banking in profitability and risk profiles: Evidence from a panel of U.S. banking institutions. Journal of International Money and Finance, 2014. 45: p. 61-73.

3. Beck, T., A. Demirguc-Kunt, and O. Merrouche, Islamic vs conventional banking: Business model, efficiency, and stability. Journal of Banking \& Finance, 2013. 37: p. 433-447.

4. Ekanayake and Wanamalie, Income Diversification and Bank Risk-Return Trade-Off: Evidence from an Emerging Economy. Asian Economic and Financial Review, 2017. 7(7): p. 644-655.

5. Grassa, R., Islamic banks' income structure, and risk: evidence from GCC countries. Accounting Research Journal, 2012. 25(3): p. 227-241.

6. Gurbuz, A.O., S. Yanik, and Y. Ayturk, Income Diversification, and Bank Performance: Evidence from Turkish Banking Sector. BDDK Bankacilik ve Finansal Piyasalar, 2013. 7(1): p. 9-29.

7. Hamdi, H., A. Hakimi, and K. Zaghdoudi, Diversification, bank performance, and risk: have Tunisian banks adopted the new business model? Financial Innovation, 2017. 3(22): p. 1-25.

8. Hardianto, D.S. and P. Wulandari, Islamic Bank Vs Conventional Bank: Intermediation, Fee Based Service Activity and Efficiency. International Journal of Islamic and Middle Eastern Finance and Management, 2016. 9(2): p. 1-18.

9. Hidayat, W.Y., M. Kakinaka, and H. Miyamoto, Bank Risk and Non-Interest Income Activities in the Indonesian Banking Industry. Economics \& Management Series, 2012. 03: p. 1-25.

10. Horne, J.C.V. and J. John M. Wachowicz, Fundamentals of Financial Management 13th Edition. 2008: Prentice Hall Inc. 
11. Kiweu, J.M., Income Diversification in the Banking Sector and Earnings Volatility: Evidence from Kenyan Commercial Banks. KBA Centre for Research on Financial Markets and Policy, 2012. 02: p. 1-32.

12. Kohler, M., Does Non-Interest Income Make Banks More Risky? Retail-versus Investment-Oriented Banks. Review of Financial Economics, 2013. 23: p. 182-193.

13. Le, T., The effect of income diversification on bank risk: Evidence from Vietnam. SSRN Electronic Journal, 2016.

14. Meslier, C., R. Tacneng, and A. Tarazi, Bank Diversification, Risk and Profitability in an Emerging Economy with Regulatory Asset Structure Constraints: Evidence from the Philippines. Archives Ouvertes, 2013: p. 1-55.

15. Molyneux, P. and J. Yip, Income diversification, and performance of Islamic banks. Journal of Financial Management, Market, and Institutions, 2013. 1(1): p. 47-66.

16. Moudud-Ul-Huq, S., et al., Does Bank Diversification Heterogeneously Affect Performance and Risk-taking in ASEAN Emerging Economies? Research in International Business and Finance, 2018: p. 1-22.

17. Nguyen, M., S. Perera, and M. Skully, Bank market power, ownership, regional presence and revenue diversification: Evidence from Africa. Emerging Markets Review, 2016: p. 1-27.

18. Nguyen, T.C., D.V. Vo, and V.C. Nguyen, Risk and Income Diversification in the Vietnamese Banking System. Journal of Applied Finance \& Banking 2015. 5(1): p. 99115.

19. Nisar, S., et al., The Impact of Revenue Diversification on Bank Profitability and Stability: Empirical Evidence from South Asian Countries. International Journal of Financial Studies, 2018. 6(40): p. 1-25.

20. Rivai, V. and R. Ismal, Islamic Risk Management for Islamic Bank 2013, Jakarta: PT. Gramedia Pustaka Utama.

21. Suhartanto, D., et al., The link between tourism involvement and service performance: Evidence from frontline retail employees. Journal of Business Research, 2018. 83(Supplement C): p. 130-137.

22. Suhartanto, D., et al., Loyalty Intention towards Islamic Bank: The Role of Religiosity, Image, and Trust. International Journal of Economics and Management, 2018. 12(1): p. 137-151.

23. Suhartanto, D., The role of store coopetition and attractiveness on the performance of tourism destination and its retail stores. International Journal of Tourism Policy, 2017. 7(2): p. 151-165.

24. Trivedi, S.R., Banking Innovations, and New Income Streams: Impact on Banks' Performance. Munich Personal RePEc Archive, 2015: p. 1-27. 